\title{
Correction: Inclusion, access and social justice: the rhizomic evolution of a field across a continent
}

Tsampiras C, Mkhwanazi N, Hume V. Inclusion, access and social justice: the rhizomic evolution of a field across a continent. Med Humanit 2018;44:218-20. doi: 10.1136/medhum-2018-011613.

In this paper, Emmanuel Omobowale was incorrectly referred to as the 'founder' of the Institute of Bioethics and Medical Humanities at the University of Ibadan, Nigeria rather than 'co-founder'. (c) Author(s) (or their employer(s)) 2019. No commercial re-use. See rights and permissions. Published by BMJ.

Med Humanit 2019;45:101. doi:10.1136/medhum-2018-011613corr1

A Check for updates 